\title{
劣質粉炭の煉炭の强度 ${ }^{1)}$
}

一一昭和 31 年 8 月 13 日受理一

\section{三井化学工業株式会社 今村良夫・今并健次・乃村精一}

要旨：先に却告した Disco 法と同一劣質粉炭を用いて煉炭を造り，生和ょび乾溜煉炭の强 度, さらに生徚炭が乾溜せられる時の强度变化を测定した。粘結剂には, 中ピッチのみよりも タールーピッチの方がよい結果をしめした。

焻石は三池沈搌粉との 2 成分配合とし，ちくら（註，焻石の中で比較的揮発分の多い乌の炎 地方名で「ちくら」とよんでいる）を配合する場合ね一度てれを乾溜して硕石と三池沈澱粉と の 3 成分配合とし, 山野上微粉は熩石和よび三池沈澱粉との 3 成分配合々すれば, 比較的少量 の粘結剤 (7.15\%対䍒炭) で生和よど乾溜品とも満足すべき强度の煉炭を造ることができた。 各種條件で造つた粗炭の $500^{\circ} \mathrm{C}$ の炉溫に和ける强度变化を测定したところ, 加熱開始後すへ

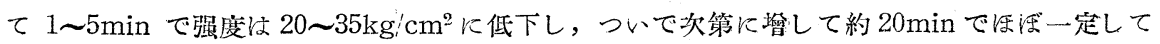
乾溜煉炭の强度となる。

熱砂乾溜法を応用して, ちくら粉を低溫乾溜する途中で生煉炭を大れて, 同時乾溜すると良 好な成績で乾溜せられた。そしてえられた乾溜ちくらは㴃石と三池沈澱粉との 3 成分配合に用 いることができる。

\section{I 緒 言}

粉炭を成型して無煙然料とし，これを高温コークス の代りにまたは補助として工業用ないし家庭用に使用 するには煉炭法が代表的な方法である。煉崖法につい ては英国 Oxford 大学の R. J. S. Jennings 民2)が最 近の各国情樊を多くの参考交献をあげて紹介した。民 の報告によればこの方法は英，独，仏などで工業的 に稼行せられており，無煙然料を製造する最も経済的 な方法の一つになろうと述へている。

塊状化の方法には煉崖法のほかに, Disco 法, 室炉 ないしレトルトによる乾溜法がある。これらの方法は 塊状化の原理が異つており，各々特長があり適当な配 合比が存在する。Disco 法3゙については先に報告した がDisco 法と同一原料を用いた時これらの方法に適 する配合比がどう違うかという意味も含めて煉㞸法に よる劣質炭の塊状化を検噞した。

\section{II 試験片作 成}

試験片作成の装置抢よびその方法はすべて資源技術 試験所の方法にしたがつた。その要旨はつぎのとおり である。

1. 成 型 器

成型器の略図は第 1 四のとおりである。えられる試 験片の大さは直径 $20 \mathrm{~mm}$, 高さ 18〜20 $\mathrm{mm}$ である。
2. 試験片作成法

乾燥粉炭 $13 \mathrm{~g}$ に粘結風 $1 \mathrm{~g}$ を加えて $14 \mathrm{~g}$ とし(粘結 㶡使用量 $=\frac{1}{14} \times 100=7.15 \%$ ），水を加えて十分加蓺 混和する。これを2等分し, さらに水を加えて十分加 熱混和し，あらかじめ $70 〜 80^{\circ} \mathrm{C}$ に加熱した第 1 困に 示した成型器に大れて加圧成型する。工業的豆孷の成 型圧力は普通 150 ～ $250 \mathrm{~kg} / \mathrm{cm}^{2}$ といわれているので， この研究では $200 \mathrm{~kg} / \mathrm{cm}^{2}$ の圧力で $3 \mathrm{sec}$ 間加圧した。

\section{第 1 図 試験片成型器（鉄）}

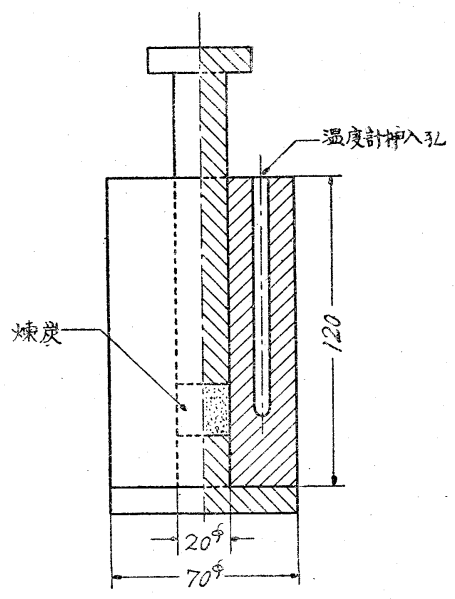




\section{第 1 表原料工業分析結果}

\begin{tabular}{|c|c|c|c|c|c|c|c|c|c|c|}
\hline 分析 & & 水 分 & 灰 分 & 揮発分 & 固定炭素 & 全硫黃 & 発熱量 & 灰 & の融点 & 点 ${ }^{\circ} \mathrm{C}$ \\
\hline 番号 & 妳 & $\%$ & $\%$ & $\%$ & $\%$ & $\%$ & $\mathrm{cal} / \mathrm{g}$ & 变形点 & 溶融点 & 溶流点 \\
\hline 13 & 田川焻石細粉 (III) & 4.70 & 20.03 & 6.85 & 68.42 & 0.28 & 6110 & 1290 & 1310 & 1330 \\
\hline 15 & 田川ちく & 3.14 & 23.50 & 17.85 & 55.51 & 0.53 & 6010 & 1300 & 1400 & $>1400$ \\
\hline 16 & 同上低溫乾溜炭 & 2.50 & 27.95 & 11.55 & 58.00 & 0.40 & 5590 & & & \\
\hline 17 & Disco コークス粉 & 2.36 & 25.35 & 12.41 & 59.88 & 0.74 & 5990 & & & \\
\hline 7 & 山野上微粉 & 2.71 & 11.31 & 39.41 & 46.57 & 0.91 & 7040 & 1380 & $>1400$ & $>1400$ \\
\hline 10 & 三 池 沈 澱 粉 & 1.45 & 17.83 & 37.78 & 42.94 & 1.45 & 6640 & 1290 & 1340 & 1350 \\
\hline 31 & 矢臨岩石 層 & 3.15 & 9.80 & 23.53 & 63.52 & 3.39 & 7370 & & & \\
\hline 12 & 三池炭中ピッチ & 0.96 & 0.45 & 50.92 & 47.67 & 0.71 & 8940 & $\mathrm{mpt}$ & Hg法) & $65.8^{\circ} \mathrm{C}$ \\
\hline 21 & 三池炭高溫タール & 痕跡 & 痕跡 & 62.00 & 38.00 & 0.90 & 9130 & & & \\
\hline 30 & 山陽パルプ廃液 & $\begin{array}{c}50 \mathrm{hr} \\
50.87\end{array}$ & $\begin{array}{c}\text { Sulfate } \\
8.50\end{array}$ & - & $\begin{array}{c}500^{\circ} \mathrm{C}, 3 \mathrm{hr} \\
4.26\end{array}$ & 2.15 & 2110 & & & \\
\hline
\end{tabular}

第 2 表 原料篩分試験結果 $(\mathrm{mm} \%)$

$\begin{array}{rlrrrrrrr} & \text { 呼 } & \text { 称 } & 0.90 \sim & 0.59 \sim & 0.42 \sim & 0.22 \sim & 0.17 & \\ 13 & <\# 20 & 21 & 22 & 12 & 13 & 30 & 2 \\ 15 & <\# 20 & 17 & 20 & 14 & 15 & 33 & 1 \\ 16 & <\# 20 & 27 & 20 & 13 & 10 & 28 & 2 \\ 17 & <\# 20 & 21 & 19 & 14 & 12 & 32 & 2 \\ 7 & <\# 20 & 13 & 16 & 17 & 17 & 35 & 2 \\ 10 & \text { 揆付の末 } & 2 & 1 & 4 & 11 & 80 & 2 \\ 31 & <\# 20 & 25 & 18 & 16 & 9 & 31 & 1\end{array}$

\section{III 耐 圧 强 度}

1. 耐圧強度測定法

試験片の耐圧強度測定は成型に用いたと同じ油圧機 で試験片が崩壊する時の最高圧力を求めた。試験片は 1 回に4 個作り, 近似の 3 数の平均值を求めた。3 数 が近似でない時は試験片を新たに 4 個造り，測定をく り返した。生煉炭の耐圧強度はバラッキが比較的大き いが乾溜煉崖の耐圧強度のバラッキは比較的小さい。

2. 耐圧強度と鉄道卜ロムメル強度との関係

上記の方法によつてえられた試験片の耐圧強度が約 $70 \mathrm{~kg} / \mathrm{cm}^{2}$ 以上あれば鉄道卜ロムメル強度 85 以上に大 体合格しうるという。

個つつ蓋付るつぼに大れ $500^{\circ} \mathrm{C} に$ 加熱した管状電気炉 で $20 \mathrm{~min}$ 乾溜後そのまま放冷して造つた。

第 2 図煏石 + 三池岸

Binder一中ピッチ $7.15 \%$ 対煉炭

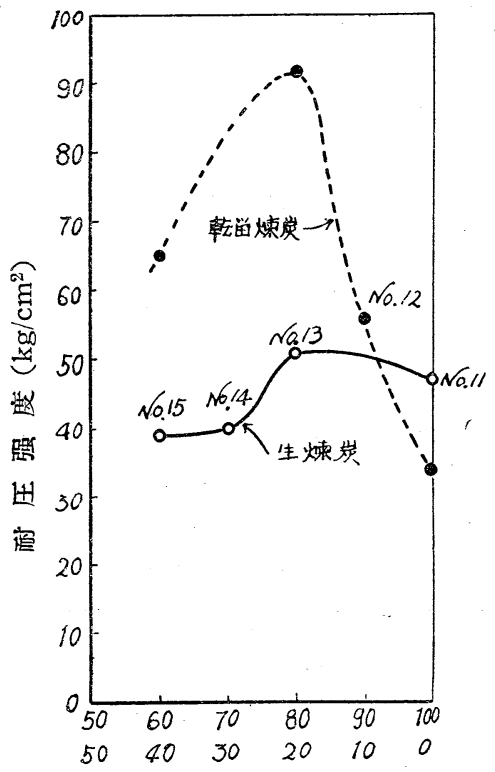

田川焬石(\%) 三池沈澱粉(\%)
第 3 図 ちくら+三池炭

Binder一中ピッチ $7.15 \%$ 対煉炭

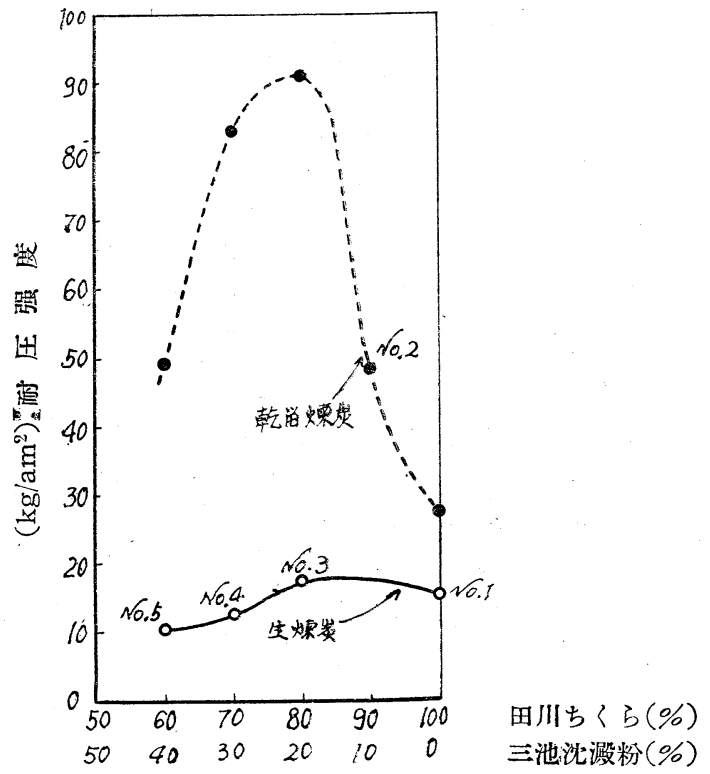


第 3 表生および乾溜煉炎の耐圧强度

（試料下端の数字は分析番号を示す）

\begin{tabular}{|c|c|c|c|c|c|c|c|c|c|}
\hline \multirow{3}{*}{$\begin{array}{l}\text { 实験 } \\
\text { 番号 } \\
\text { No. }\end{array}$} & \multirow{3}{*}{ 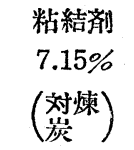 } & \multicolumn{6}{|c|}{ 原料炭配合比（粘絬剈を除く） } & \multirow{2}{*}{\multicolumn{2}{|c|}{ 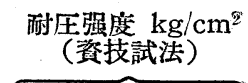 }} \\
\hline & & \multirow{2}{*}{$\begin{array}{c}\text { 田川焬石 } \\
\text { 細粉( III) } \\
13\end{array}$} & \multirow{2}{*}{$\begin{array}{c}\text { 田川さく } \\
(V) \\
15\end{array}$} & \multirow{2}{*}{$\begin{array}{l}\text { 田川ちく } \\
\text { 低盢幹溜炭 } \\
16\end{array}$} & \multirow{2}{*}{$\begin{array}{c}\text { Disco } \\
\Rightarrow \begin{array}{c}\text { Z } \\
17 \\
17\end{array}\end{array}$} & \multirow{2}{*}{ 微 ${ }_{7}^{\text {野 }} \frac{\text { 上 }}{\text { 粉 }}$} & \multirow{2}{*}{$\begin{array}{l}\text { 至 池 } \\
\text { 沈澱 } \\
10\end{array}$} & & \\
\hline & & & & & & & & 生煉炭 & 乾留煉炭 \\
\hline 1 & 中ピッチ & - & 100 & - & - & - & - & 15 & 27 \\
\hline 2 & $"$ & 90 & - & - & - & - & 10 & - & 48 \\
\hline 3 & " & - & 30 & - & - & - & 20 & 17 & 91 \\
\hline 4 & $"$ & - & 70 & - & - & - & 30 & 12 & 83 \\
\hline 5 & $"$ & - & 60 & - & - & - & 40 & 10 & 49 \\
\hline 11 & " & 100 & - & - & - & - & - & 47 & 34 \\
\hline 12 & $"$ & 90 & - & - & - & - & 10 & - & 56 \\
\hline 13 & $"$ & 80 & - & - & - & - & 20 & 51 & 92 \\
\hline 14 & $"$ & 70 & - & - & - & - & 30 & 40 & - \\
\hline 15 & " & 60 & - & - & - & - & 40 & 39 & 65 \\
\hline 31 & \multicolumn{2}{|c|}{ 中ピツチ+タール 100} & - & - & - & - & - & 109 & 16 \\
\hline 32 & " & 90 & - & - & - & - & 10 & 91 & 64 \\
\hline 33 & " & 80 & - & - & - & - & 20 & 81 & 63 \\
\hline 34 & " & 70 & - & - & - & - & 30 & 93 & 99 \\
\hline 35 & $"$ & 60 & - & - & - & - & 40 & 104 & 81 \\
\hline 36 & " & - & 100 & - & - & - & - & 10 & 1 \\
\hline 37 & $"$ & - & 90 & - & - & - & 10 & 21 & 31 \\
\hline 38 & $"$ & - & 80 & - & - & - & 20 & 39 & 57 \\
\hline 39 & $"$ & - & 70 & - & - & - & 30 & 64 & 99 \\
\hline 40 & $"$ & - & 60 & - & - & - & 40 & 13 & 73 \\
\hline 41 & $"$ & 60 & - & - & - & 20 & 20 & 89 & 86 \\
\hline 42 & " & 40 & - & - & - & 40 & 20 & 78 & 70 \\
\hline 43 & " & 20 & - & - & - & 60 & 20 & 104 & 60 \\
\hline 44 & " & - & - & - & - & 80 & 20 & 122 & 31 \\
\hline 45 & $"$ & - & - & - & - & 100 & - & 78 & 1 \\
\hline 46 & " & - & - & - & - & 60 & 40 & 52 & 26 \\
\hline 47 & " & 60 & 20 & - & - & - & 20 & 60 & 88 \\
\hline 48 & $"$ & 40 & 40 & - & - & - & 20 & 57 & 88 \\
\hline 49 & " & 20 & 60 & - & - & - & 20 & 65 & 70 \\
\hline 50 & " & - & - & 60 & - & - & 40 & 55 & 43 \\
\hline 51 & " & - & - & 70 & - & - & 30 & 57 & 70 \\
\hline 52 & " & - & - & 80 & - & - & 20 & 60 & 78 \\
\hline 54 & " & - & - & 100 & - & - & - & 52 & 10 \\
\hline 55 & " & 20 & - & 60 & - & - & 20 & 75 & 75 \\
\hline 56 & " & 40 & - & 40 & - & - & 20 & 80 & 70 \\
\hline 57 & " & 60 & - & 20 & - & - & 20 & 75 & 85 \\
\hline 58 & $"$ & - & - & - & 80 & - & 20 & 103 & 117 \\
\hline & & IV 試 & 料 & & 2. 考 & 察 & & & \\
\hline & 㘰は先の D & co 法に用 & ・たものと同一 & のもものを用 & $(1)$ & 中ピッチの & みを粘結凧 & した煉炭 & \\
\hline いた & 試料の工 & 分析站よび & "篩分試験の綡 & 锞は第1表 & ピッチ & 徚炭では普 & 通 $10 \sim 15 \%$ & 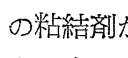 & ら使用せら \\
\hline およ & 第 2 表の & おりである & 。試粼は第 & 表に示した & れており & ，その便用 & 量はある程 & 多い方が自 & 煉炭の強 \\
\hline そお & ) $20 \times ッ=$ & 二以下に粉碚 & 氿した。 & & 度が大き & い。Disco & 法では硬 ピ & 于約 $5 \%$ & 連用した場 \\
\hline & $\nabla$ 生 & および乾溜火 & 柬炭の耐圧强 & & 合の成績 & 功よかつた & が，この研 & こではDisc & 法と比較 \\
\hline 1. & 実験 結果 & & & & するのを & 目的とする & ため硬と゚ッ & ー5\%にみさ & らう量とし \\
\hline $\begin{array}{l}\text { 生 } \\
\text { おうり }\end{array}$ & $\begin{array}{l}\text { および乾溜 } \\
\text { である。 }\end{array}$ & 䊺の耐圧強 & 度測定結果 & 第 3 表のと & $\begin{array}{l}\text { て粘結倣 } \\
\text { 中ピッ }\end{array}$ & $\begin{array}{l}\text { リの量な } 7.15 \\
\text { チのみ } 7.15\end{array}$ & $\begin{array}{l}\% \text { （対煉㟶 } \\
\% を \text { 使用乙 }\end{array}$ & $\begin{array}{l}\text { に一定した } \\
\text { 「煣石十三 }\end{array}$ & $\begin{array}{l}\text { 二。 } \\
\text { 池沈澱粉士 }\end{array}$ \\
\hline
\end{tabular}


第 4 図煽石 + 三池宸

Binder一中ピッチ十タール(1:1)7.15\%

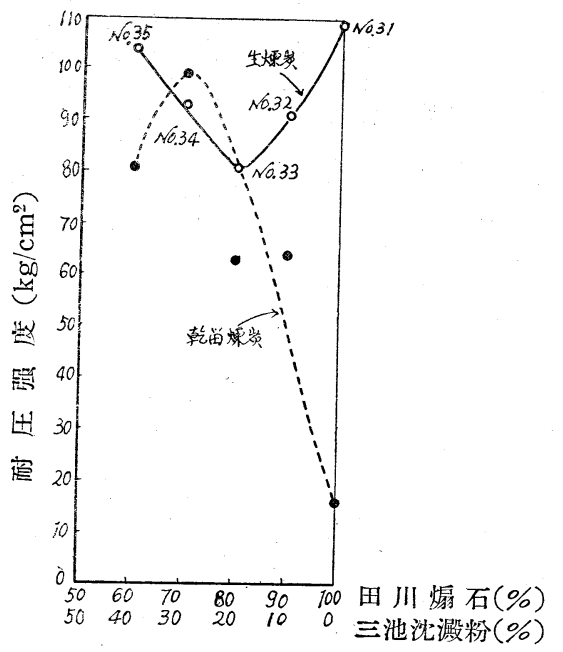

および「ちくら十三池沈搌粉」を原料として造つた生 および乾溜煉崖の耐圧強度は第 2 図抢よび第 3 困のと おり，乾溜煉宸の強度は焐石またはちくらが65～85\% の範囲で，70〜 $90 \mathrm{~kg} / \mathrm{cm}^{2}$ の強度をしめし良好である が生徚炭の強度は, 特にちくら配合の場合に低い值を しめし笑用性にとぼしい。

（2）中ピッチ十高温ターールを粘結㶡とした煉宸 ドィッでは最近タール油の併用によつて粘結郕を 4

第 5 図 ちくら+三池炭

Binder一中ピッチータール (1: 1)7.15\%

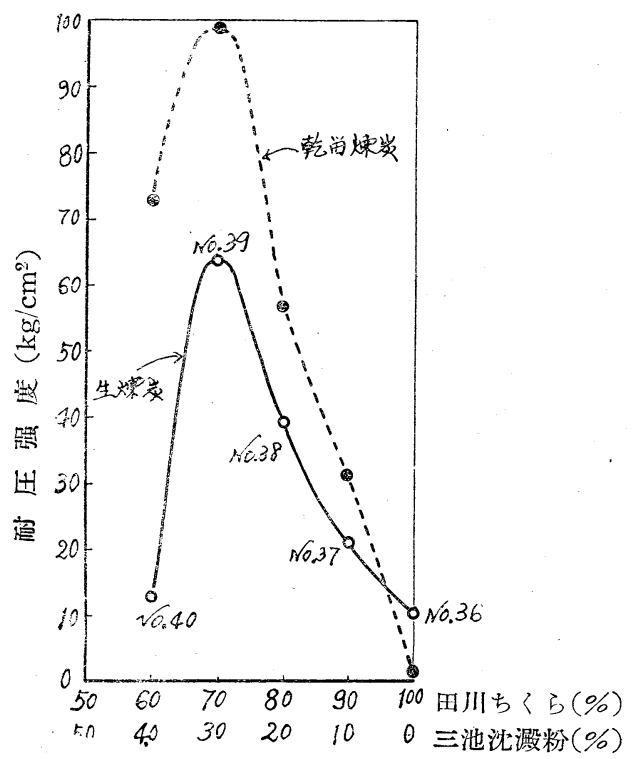

第 6 図 乾溜ちくら+三池沈澱粉

Binder一中ピッチナタール (1: 1)7.15\%

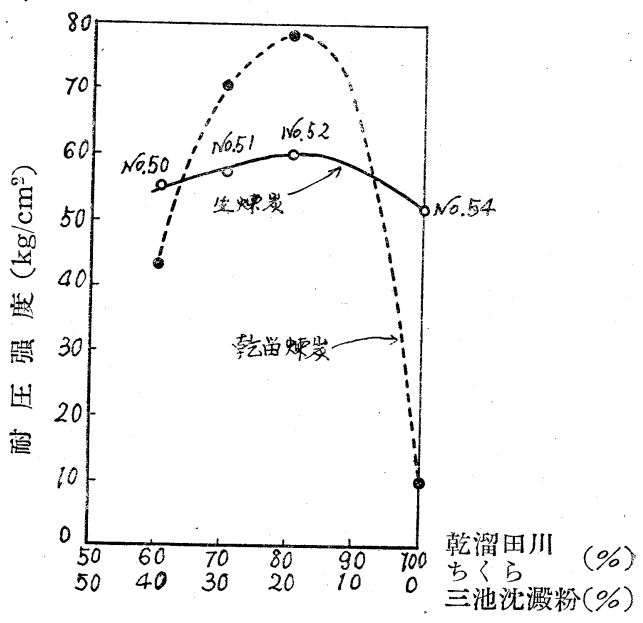

〜 5\%に減じえたといわれです)いるのにならつて，中 ピッチ十高温タール $(1: 1)$ を上と同じく $7.15 \%$ 使つ て燤孷を造つた。ダール・ピッチ系徚炭の耐圧強度は 第4〜7図のとおりである。

a ) 焬石 + 三池沈搌粉

第 4 図にみると扣り，田川煽石約 60〜80\% の範囲 で生および乾溜徚炭とも十分の強度がえられた。

第 7 図 山野上微粉三池沈澱粉

Binder一中ピッチータール (1: 1) $7.15 \%$

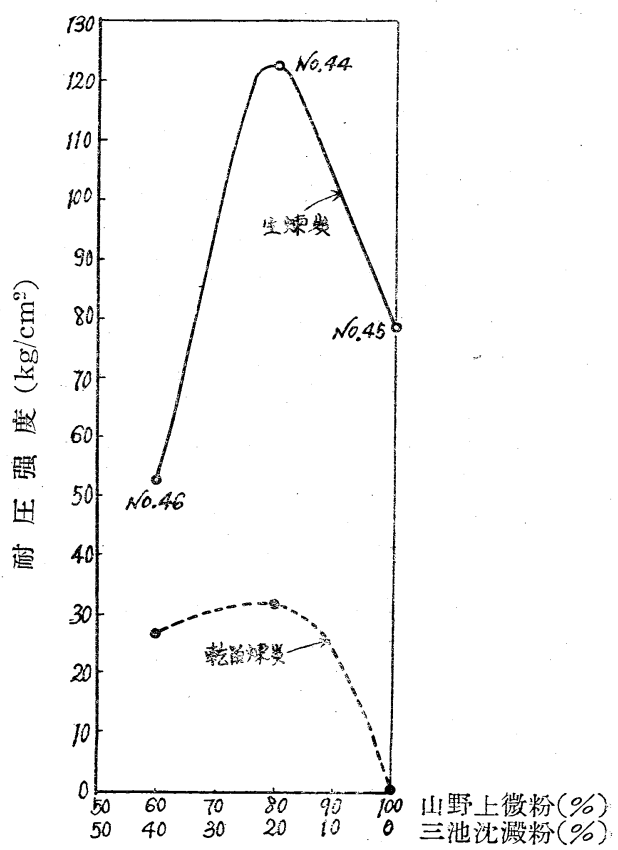


第 8 図 煏石十ちくら十三池沈澱粉

Binder一中ピッチナタール (1:1)7.15\%

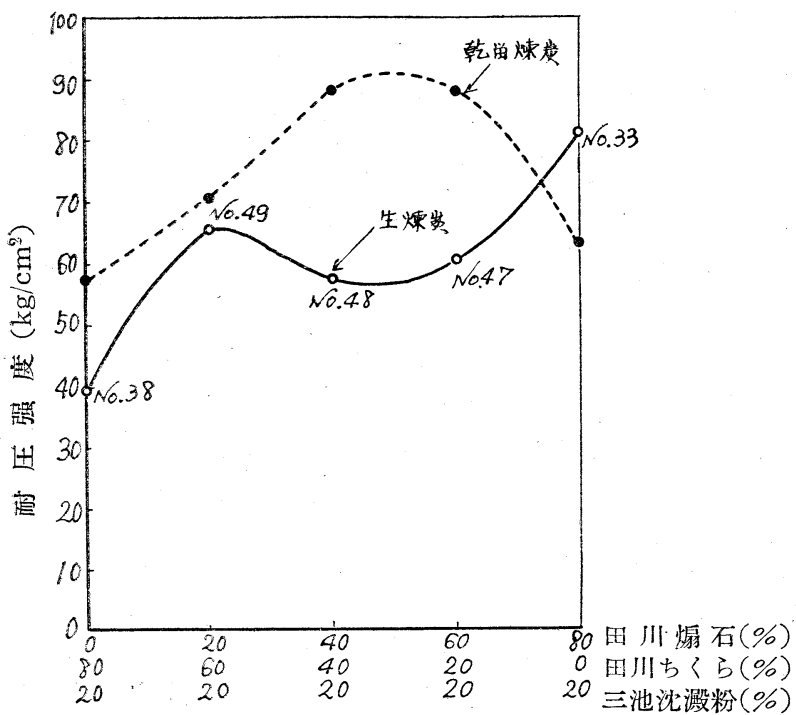

なつた洁かはbの場合と著しい差異をみとぬ ない。

d）山野上微粉十三池沈洪粉

揮発分 $39.41 \%$ 㧀もつ山野上微粉と三池沈 澱粉との䍒炭の強度は第7困のとおり, 生熯 炭の強度はすぐれているが乾溜燤炭の強度は はなはだ悪い。

e) 焻石十ちくら+三池沈搌粉

第 8 図は三池沈洪粉を20\%に一定し，田川 焻石および田川ちくらを種々の割合で配合し た場合である。3 成分が共存する時, 斡溜棣

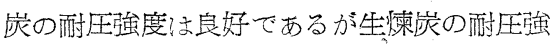
度は約 $60 \mathrm{~kg} / \mathrm{cm}^{2}$ て若干低い。

f）焻石十乾溜ちくら+三池沈澱粉

さきにちくら十三池沈澱粉の煉炭でちくら を乾溜して配合卞ると, 乾溜徚孷の強度が低 下子るが生楝炭の強度は配合比の变化に対し て変動が少なくなつた。3成分配合の場合に

b ) ちくら十三池沈澱粉

第 5 図にみるとおり，タール・ピッチ系粘結凧の使 用によつて, 中ピッチのみの場合にくらぶて, 特に生 煉炭の強度がよくなつたがまだ十分でない。

c) 乾溜ちくら+三池沈洪粉

$\mathrm{b}$ の配合の生莱炭の強度が低いのはちくらの揮発分 の量に関係するものと考え,ちくらを $500^{\circ} \mathrm{C}$ で約 $1.5 \mathrm{hr}$ 低温乾溜し，揮発分を $11.55 \%$ に減した場合の煉炭の 强度は第 6 図のとおり，乾溜ちくらの配合範囲が広く

\section{第 9 図 煽石十乾溜ちくら十三池沈澱粉}

Binder一円ピッチナタール (1: 1) 7.15\%

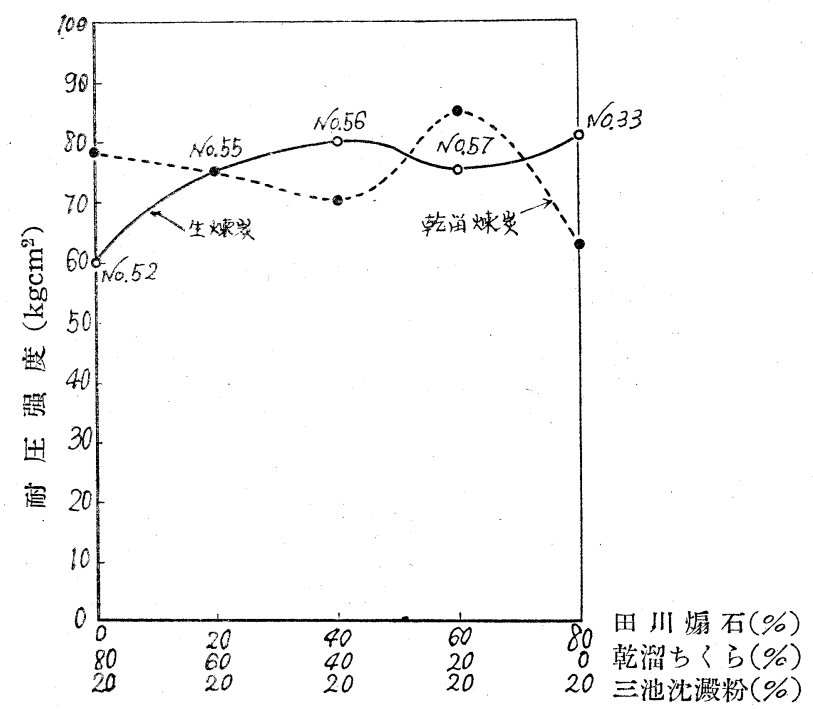

もちくら存乾溜して配合したところ，第 9 図にしめ古 ように, 乾溜煉岸の強度によ若干低下寸るが生惈炭の強 度は上昇して 75〜 $80 \mathrm{~kg} / \mathrm{cm}^{2}$ となり，生抢よび乾溜煉 炭の強度はほほ満足寸心き值に達した。しかも比較的 ひろい配合範囲にわたつて強度の変化が少ないことを しめしている。

g) 焐石十山野上微粉十三池沈搌粉

この3 成分配合の場合は第10园にみるとおり，三 池沈澱粉 $20 \%$ に一定した時，山野上微粉 40〜10\%の 範囲で生抢よび乾溜谏炭の強度はほほ渵足す 心き值をしめした。なお山野上微粉配合煉炭 は第10図抢よび第7図:こみるとおり，他の 例とことなつて生湅炭の強度が乾溜煉宸の強 度よりも高小值をしめ吉現象がみられた。

h) コークス粉十三池沈洪粉

コークス粉としてDisco コークス粉を80\% と三池沈洪粉 $20 \%$ の場合についてのみ強度を 測定したところ，生打よび乾溜煉炭はそれぞ

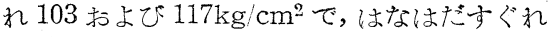
た值をしめした。

i ）以上 $\mathrm{a} \sim \mathrm{h}$ の配合試験の結果を綜合す ると, 䎅石は三池沈洪粉との 2 成分配合とし

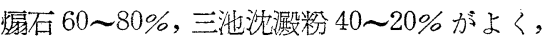
ちくら省配合するには一度乾溜して煬石と三 池沈洪粉との 3 成分配合とし, 山野上微粉は 焻石 40 70\%，三池 20\% との3 成分配合と すれば比較的少量の粘結刘 (7.15\%対徚宸) 
第 10 図 煽石十山野上微粉 + 三池沈澱粉

Binder一中ピッチナタール (1: 1)7.15\%

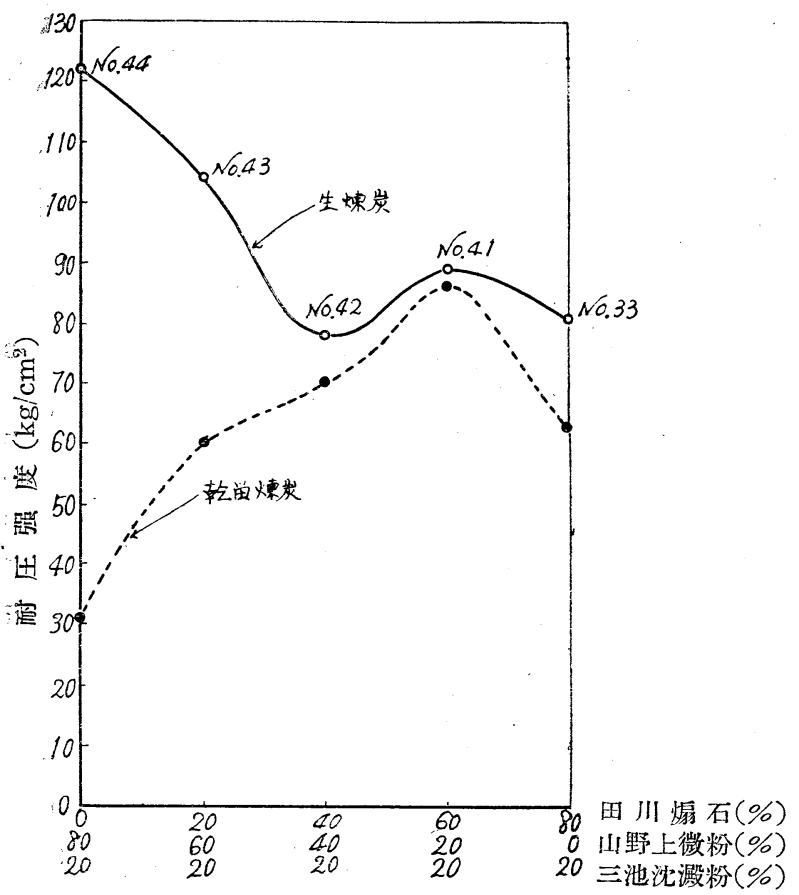

熱するようにした Brennstoff-Technik 法 (B-T 法 ${ }^{899)}$ )などが考案せられ，かつ一部 のものは工業化されている。

丹野氏ら ${ }^{9)}$ は Otto 炬に似た㟶研式乾留炉 について報告し，炉底を $600^{\circ} \mathrm{C}$ ，炉中心を $500^{\circ} \mathrm{C}$, 炬頂を $450^{\circ} \mathrm{C}$ 位にすると困難なく乾 溜が行われると述へた。

このように乾溜中に抢ける煉炭の強度は大 きな問題であるが今まで具体的に報告せられ たものをあまりみないので，この研究では焻 石を配合した種々の煉炭につ心て強度变化を 求めた。

\section{1. 実験装置}

実験装置は油圧機上に第11 困にしめした 堅型管状電気炉を虎の, 炉内に 2 個の鉄棒 $\mathrm{a}$, $\mathrm{b}$ 觉入れ， a , b の間に熯炭の試験片をはさ みうるようにしたものである。

\section{2. 笑 験 法}

第 11 図の電気炉内の鉄棒 a をとりさつ て温度計をさしこみ，石綿布でふだし，電 気炬に電流を通じて, 炬温を $500^{\circ} \mathrm{C} に$ 保つ。 鉄棒 $\mathrm{a}$ は別の電気灯て $500^{\circ} \mathrm{C}$ に熱しておく。
で满足すべき強度の燤炭を造ることができる。

\section{VI 加熱時における生煉孷の强度変化}

徚炭を原料としてがス発生をおこなうにはは，先づ徚 炭を乾溜してタールを除いてのち発生炬に装入するか または生莱炭をとのまま発生炉に装大寸るいわ的る Coal Water Gas 法とがある。後の方法はタールによ る困難をともなうこともあるが一般: こ熱経済上有利て ある。

いづれの方法によるも生煉炭が乾溜される過程にお ける強度の変化が問題であり, 徚炭の軟化が著しい時 は煉炭相互が融着するにいたる5゙。このような煉炭の 融着ない乙弱化は煉炭な燃焼する場合にはほとんど問 題とならないが乾溜の場合には種々の困難を起すこと はよくきくとおりである。燥炭の燃焼時には萰炭が急

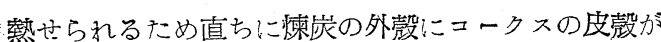
形成せられて融着ないし弱化が起らず，かつ然料層が 浅いため加熱時の強度の点も問題とならないががス化 の場合には従来の形式の乾溜炉では急熱が行われ難い から煉炭の融着弱化が起り勝ちとなる。

そこで急熱が容易に二行われるため熱がス在横向また は上向に生熯崖層に通す方法，例えば Otto の横流式 师6)，Lurgi の Spülgas 法2)，熱がスの代りに熱砂中 で乾溜するWeber 法2),゙，また炬幅をせまくして急
ついで煉孷試験片を鉄棒 $\mathrm{b}$ 上におき，直ちにストップ ウォッチを始動し，電気炉上部開放端を石綿布でふた し，空気が流入しないようにする。一定時間後石綿布 そ温度訪とを取りのぞいて，代りに別に $500^{\circ} \mathrm{C} に$ 加熱

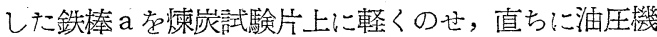
にて加圧し，油圧機の圧力計の最高值をよみとる。圧 力計の指針は試験片が軟化中はある一定值を指したまま ま停止するが，試験片がコークス化した場合には，あ る最高值に澾してのち直ちに下降する。なおこの場合

\section{第 11 図 煉炭加熱時の强度变化測定炉}

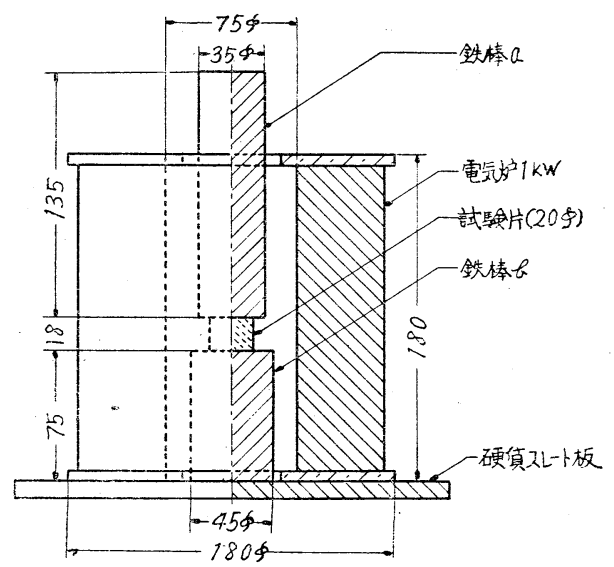




\begin{tabular}{|c|c|c|c|c|c|c|c|}
\hline 实験番号 & 粘結刘の & 粘結㨈の & 成型圧力 & & 检炭配合比 \% & （粘結剂老除 & \\
\hline No. & 種＼cjkstart類 & $\begin{array}{l}\text { 使 用 量 } \\
\% \text { 対煉炭 }\end{array}$ & $\mathrm{kg} / \mathrm{cm}^{2}$ & $\begin{array}{l}\text { 互川煫石 } \\
\text { 細粉 (III) }\end{array}$ & $\begin{array}{l}\text { 田川占くら } \\
\text { 低溫乾溜炭 }\end{array}$ & 三池沈澱粉 & 矢岳岩石曆 \\
\hline 59 & タールナピッチ & 7.14 & 200 & 70 & - & 30 & - \\
\hline 60 & $=$ & 7.14 & 200 & 40 & 40 & 20 & - \\
\hline 61 & " & 7.14 & 500 & 70 & - & 30 & - \\
\hline 62 & パルプ廃液 & 7.14 & 200 & 70 & - & 30 & - \\
\hline 63 & " & 14.3 & 200 & 70 & - & 30 & - \\
\hline 64 & タール十ピッチ & 7.14 & 200 & 70 & - & - & 30 \\
\hline
\end{tabular}

第 5 表 煉炭の加熱時における强度变化 (炬溫 $500^{\circ} \mathrm{C}, \mathrm{kg} / \mathrm{cm}^{2}$ )

\begin{tabular}{|c|c|c|c|c|c|c|c|c|c|c|}
\hline 官験 & & & 加 & 燓 & 時 & 間 & $\min )$ & & & \\
\hline No. & 0 & 1 & 2.5 & 5 & 7.5 & 10 & 12.5 & 15 & 20 & 25 \\
\hline 59 & 88 & - & 20 & 22 & - & 25 & 43 & 55 & 75 & 75 \\
\hline 60 & 80 & 20 & 20 & 18 & 24 & 27 & - & 56 & 70 & - \\
\hline 6 & 174 & 27 & 23 & 25 & - & 25 & - & 40 & 63 & - \\
\hline 62 & 68 & - & 57 & 25 & - & 34 & - & 35 & 50 & 52 \\
\hline 63 & 50 & - & 43 & 36 & - & 33 & - & 38 & 45 & \\
\hline & 135 & - & 20 & 23 & - & 26 & - & 19 & 17 & \\
\hline
\end{tabular}

耐圧強度測定值のバラッキは少なかつた。

3. 試 験 片

第 12 目 煽石を配合した各種煉炭の加熱時の强度变化 (炉溫 $500 \sim 480^{\circ} \mathrm{C}$ )

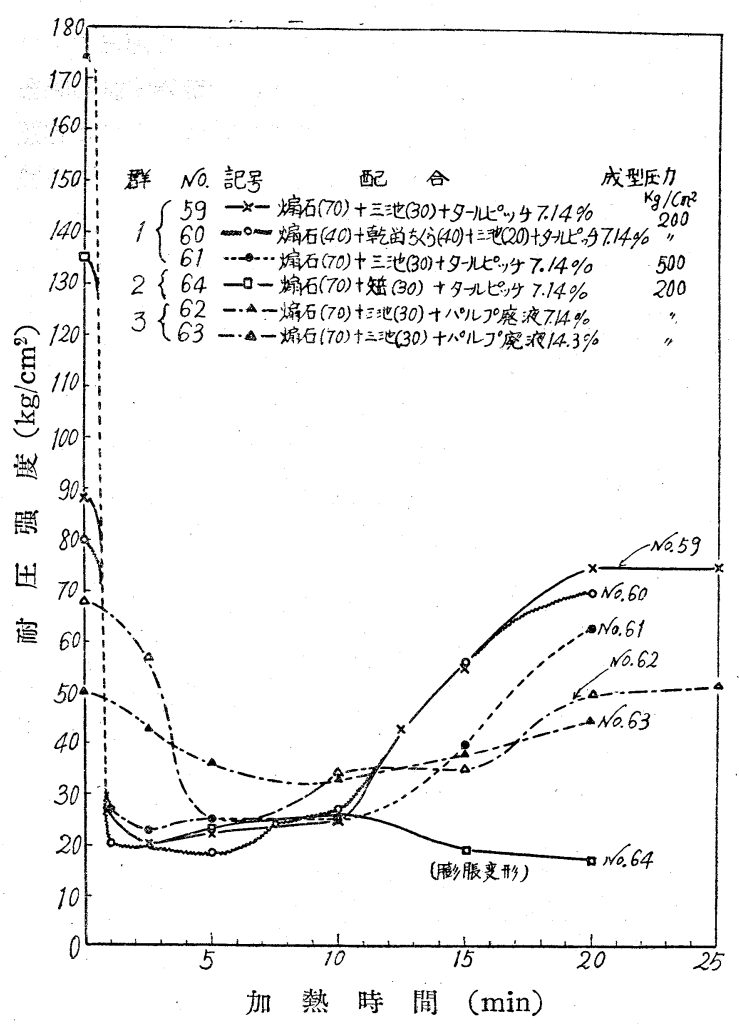

先に第 1 表抢よび第 2 表にしめした原料を用い，資 源技術試験所法で第 4 表にしめした條件て試験片をつ くつた。

\section{4. 実験結果}

実験結果は第 5 表のと扤りであり，これを図示する と第 12 目となる。

\section{5. 考察}

第12図の各種煉炭の強度变化曲線は大別して 3 群に わけられる。

その一つは粘結剤にタール十ピッチを使用し，加熱 中煉炭が大きく膨脹変形しないもの( 1 群)，つぎは同 しくタール・ピッチ系粘結剤を使用するが配合炭の 粘結性が過多のため, 加熱中に煉炭が著しく膨脹変 形するもの( 2 群), 他はパルプ廃液を粘結刘!に使用 するもの( 3 群)である。

1 群は三池沈搌粉を 20〜30\% 配合した場合で， 配合㞸抢よび成型圧力の差によつて生煉炭の強度に は大きい差があり，特に成型圧力を $500 \mathrm{~kg}^{\prime} \mathrm{cm}^{2}$ と したものは $174 \mathrm{~kg} / \mathrm{cm}^{2} に お よ ふ ゙ か ゙ ， 500^{\circ} \mathrm{C}$ の炉に煉 炭を大れるとその強度は3例とも直ちに約 $20 \mathrm{~kg} / \mathrm{cm}^{2}$ に急下降する。ついで約 $10 \mathrm{~min}$ 後, 䍒宸のコークス 化が進行して強度は次第に上景し, 約 $20 \mathrm{~min}$ 以後 ほほ一定する。この場合成型圧力 $500 \mathrm{~kg} / \mathrm{cm}^{2}$ のもの (No. 61) は同一配合の $200 \mathrm{~kg} / \mathrm{cm}^{2}$ のもの (No. 59) にくらへて生燔炭の強度は約 2 倍であるが乾溜煉崖 の強度はもしろ低い。恐らく大きい成型圧力のた め, 配合㞸粒子間の空㗂が乾溜:こよる粒子の膨脹度 にくらへて小さく，このため煉炭が多少変形するた め，または大きい成型圧力による内部に残つている 圧力が, 乾溜時に除ふれて煉炭が多少変形するため と考えられる。

2 群は三池沈澱粉の代り:こ矢岳炭を $30 \%$ 配合した 場合で; 煉㟶を $500^{\circ} \mathrm{C}$ の炉: こ入ると，その強度は 1 群と同様に二直ちに約 $200 \mathrm{~kg} / \mathrm{cm}^{2}$ に急下降する。し かし矢岳炭の配合率が多く,粘結性過多のため,加熱 によつて燤㞸は膨脹変形し，コークス化しても一度 
下降した強度曲線は上昇しない。この場合，矢岳炭の 配合率を低隇すれば，その強度曲線は 1 群のものに近 づくはずである。

3 群はパルプ廃液を粘結荗:こ用いた煉炭である。こ の煉炭は作成後 3 日経過したもので生煉炭の強度は同 一配合の No. 59 の $88 \mathrm{~kg} / \mathrm{cm}^{2}:$ にらべて幾分低く, 50 〜 68kg/ $\mathrm{cm}^{2}$ である。これ攀すると，タール・セ゚ ッチ系粘結倣を使用した場合のような急激な強度の低 下はないが, 枯崖を死: こ入れて後, 約 $5 \mathrm{~min}$ て強度は $25 \sim 30 \mathrm{~kg} / \mathrm{cm}^{2}:$ : 低下する。1 群之同様加熱開始後, 約 $10 \mathrm{~min}$ で強度曲線はわずかに上昇しはじめ, $20 \mathrm{~min}$ 以後注活一定するがコークスの強度は 1 群のものにく らべて低い。

以上 1 3 群は実験例は少ないが,生燤炭の強度は製 造條件によつてはなはだしく相違するも，加熱によつ て，いつれも $20 〜 30 \mathrm{~kg} / \mathrm{cm}^{2}$ という比較的強度の弱い 状態となり，ついで乾溜が進行しニークス化するにし たがつて徐々にこの強度を增す。粘結炭の配合が多す ぎて加熱による膨脹変形の著しい煉炭の強度は低い。 また $20 \mathrm{~kg} / \mathrm{cm}^{2}$ の耐圧力があれば普通の乾溜炉では作 業:に困難を生じないと考元られるが，惯孷が急熱せら れない形式の炉では煉炭はその荷重:こまけておしつぶ されるものと考元られる。

\section{VII 熱砂乾溜法の応用}

徚炭苍乾溜寸る時, 問題となるのは徚炭の軟化融着 である。これをさけるため前にのべたように，熱がス 法, 狭幅炬法, 熱砂法などの急熱法が行われるが,この 研究の場合，熱砂法の忘用が興味深い之考元られる。

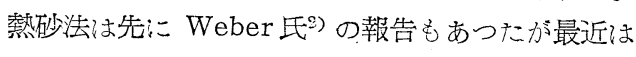
Gillings (10)もこの方法の発 表を行つている。この方法の 概要は熱砂を入れた迴転炬: 二 生煉崖を入れ，熱砂之煉炭と が直接接触し急速かつ效果的 な乾溜を行わしめるものであ る。

前に述へたように三池沈澱粉 は20\%以上の水分をもつてい るので, ある程度これを乾燥 する必要があること，ちくら は一度約 $500^{\circ} \mathrm{C}$ で乾溜したも の配合すると橱石，三池炭 の 3 成分配合によつて徚炭の 強度が大きくなるという理由 から第14図のような製造工程
が考えられる。

まずちくらを適当の粒度に粉砕し，第 1 迴転炉で約 $30 \mathrm{~min}$ 乾溜する。第 2 廻転炉: 二生煉炭を装大して熱砂 法の原理にしたがつてちくら粉と生煉炭を約 $1 \mathrm{hr}$ 同時 乾溜する。乾溜後, 第 2 廻転炬を出た混合物をバース クリーンで分別し乾溜煉炭は熱いまま水性ガス発生炉 に送る。一方約 $500^{\circ} \mathrm{C}$ の乾溜ちくら粉には別に粉据し た焬石粉を配合してその温度を $250 〜 300^{\circ} \mathrm{C}$ : 二冷却し， さらにこれに水分の多い三池沈澱粉と粘結剤としてタ ールトピッチ混合物を添加してニーダーに送る。ここ で粘結郕を原料:こ十分混和せしめて後成型機で熯孷と する。

この研究では焻石 (40) +畭溜ちくら (40) +三池沈 澱粉 (20) の卵型煉㟶を造り, Fischer 迴転师でちく ら粉中で試験的に乾溜してみた所, 枯炭は变形ないし 融着することなくまた摩耗も殆ざなく良好な成績で 乾溜せられた。

\section{IIII 総一括}

（1）先に報告したDisco 法々同一の劣質粉炭試料 を用いて煉炭を造り，生抢よび乾溜煉炭の強度，さら に生煉炭が乾溜される時の強度变化を測定した。

（2）試験片の作成，陾圧強度測定法は資源技術試 験所の方法によつて行つた。

（3）この研究では粘結剽使用量をす心゙て 7.15\% (対燤㟶)に一定した。

(4) 粘結剤にには中ピッチのみよりもタール・ピッ チ系の方がよい結果危しめした。

（5）煽石は三池沈澱粉との 2 成分配合之し，焻石 60 80\%，三池 40２0\% がよく，ちくら配合する

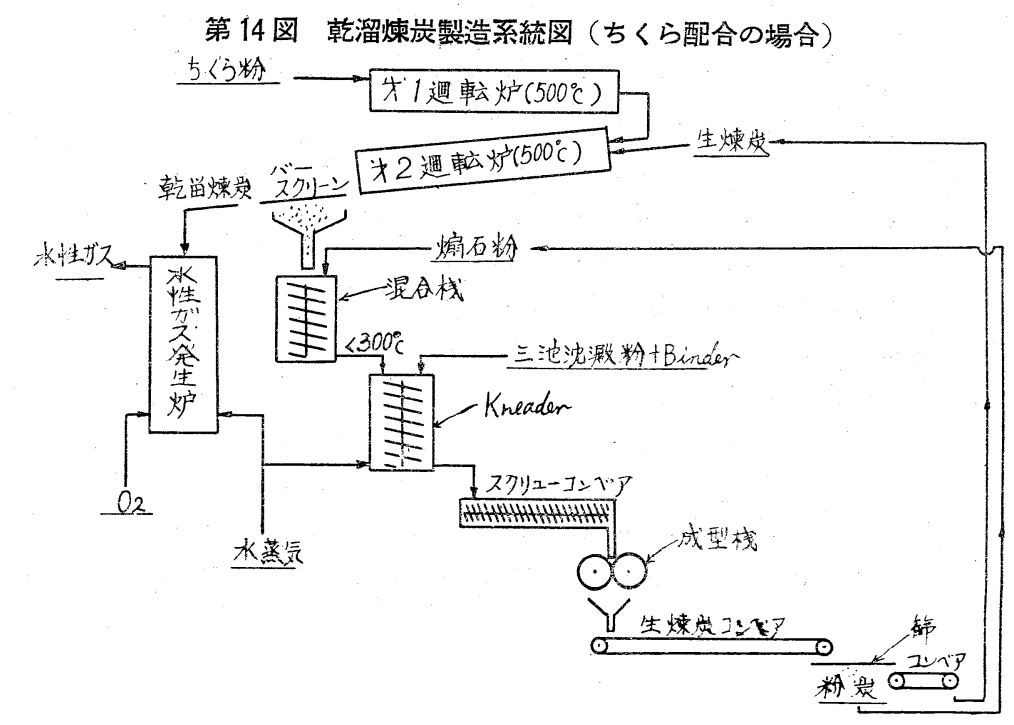


には一度これを乾溜して焻石と三池沈澱粉との 3 成分 配合とし，山野上微粉は焗石 40〜 70\%，三池 20\% と の 3 成分配合とすれば比較的少量の粘結㓮 (3.75\%)で 满足す心き強度の徚炭を造ることができる。特に㵊石 十乾溜ちくら十三池沈潑粉の配合熯孷は広い配合範囲 に扎て，生および乾溜煉炭の強度が $70 〜 80 \mathrm{~kg} / \mathrm{cm}^{2}$ であつた。

（6） $500^{\circ} \mathrm{C}$ の炉温に抢ける生煉宸加熱時の強度変 化を測定したところ，粘結郕にタール・ピッチ系また はパルプ廃液を用いたもの,"ないし成型圧力 200〜500 $\mathrm{kg} / \mathrm{cm}^{2}$ でも, みな加熱開始後, 1 5min で弓強度が 20 $\sim 35 \mathrm{~kg} / \mathrm{cm}^{2}$ に低下し，ついて強度は次第に二増して約

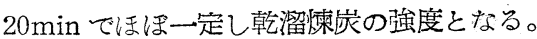

（7）耐圧強度 $20 \mathrm{~kg} / \mathrm{cm}^{2}$ あれば普通の乾溜炉では 作業に困難を生じないと考元られるが煉炭が急熱され ない形式の炉では熯炭はその荷重にまけておしつぶさ れるものと考元られる。

（8）熱砂乾溜法を応用して, ちくら粉を低温乾溜 する途中で生煉炭を入れて混合乾溜すると燤炭は変形 ないし融着することなく良好な成績で乾溜せられた。 そして乾溜せられたちくら粉は（5）にのバたように
焻石と三池沈潑粉との 3 成分配合煉炭とすれば生打よ び乾溜品とも満足す心きき強度のものとなる。

終りにこの研究:ニ当り試料の提供抢よび分析との他 種々御便宜をたまわつた三半鉣山株式会社に対し，ま たこの研究の発表を許可せられた三井化学工業株式会 社に二対し深く感謝する。

$$
\text { 文献 }
$$

1）燃料協会第 293 回例会講演，昭和 31 年 7 月 10 日， （於日本釷業会館講堂）

2) R.J.S. Jennings, Chem. Process Eng., Nov., 343 9 (1953)

3）今村良夫, 今井建次, 乃村精一, 燃協誌, 35,577 (1956)

4) 丹野晴彥, 炭研, 5, 42 55 (1954)

5) A. Thau, Brennstoff schwellung, Band I, Verlag von Wilhelm Knapp, Halle, s 149, (1949)

6) G. Lorenzen, Brenn.-Ohemie, 34, 233 7,(1953)

7) A. Thau, Brennstoffschwellung, Band I, s.s. 374 7

8) ibid, s.s. $75 \sim 83$

9）丹野晴彥，原登志美，炭研， 5, 1 13(1954)

10) D. W. Gillings, Gas World, 143, Cok. Sec., 25 (1956)

\title{
STRENGTH OF BRIQUETT OF POOR COAL POWDER
}

\author{
by Yoshio Imamura, Kenji Imai \& Seiichi Nomura \\ (Mitsui Chem. Ind. Co., Ltd.)
}

SYNOPSIS :-The relation between blending ratio and strength of uncoked and coked. briquett was studied.

Binder of $7.15 \%$ of briquett was used. As binder, coal tar plus soft pitch (1:1) was. better than soft pitch only.

Suitable ratio of Senseki/Miike precipitated fine coal is $60 \sim 80 / 40 \sim 20$. When Chikura is used, it must be carbonized previously and blended with Senseki and Miike precipitated fine coal. Strength of uncoked and coked briquetts made of carbonized Chikura, Senseki and Miike precipitated fine coal are $70 \sim 80 \mathrm{~kg} / \mathrm{cm}^{2}$ at wide blending range. Yamano powder may be blended with Senseki (40 70\%) and Miike precipitated fine coal (20\%).

Transition of strength of briquett during carbonization was studied. Briquett binded with tar plus pitch or pulp waste liquor and pressed by the pressure of $200 \sim 500 \mathrm{~kg} / \mathrm{cm}^{2}$ decrease its strength to $20 \sim 35 \mathrm{~kg} / \mathrm{cm}^{2}$ in $1 \sim 5 \mathrm{~min}$. after briquett is put in furnace heated at $500^{\circ} \mathrm{C}$, and then increase its strength in $20 \mathrm{~min}$. and become constant, thereafter.

We think that strength of $20 \mathrm{~kg} / \mathrm{cm}^{2}$ is enough to gasification or carbonization.

In this study, "carbonization in hot sand" method was applied. Briquett was carbonized in hot $\left(500^{\circ} \mathrm{C}\right)$ Chikura powder in rotary retort, we got a good result. 